\title{
New morphological data from the Jurassic of Inner Mongolia confirms the damselfly aspect of Protomyrmeleontidae (Insecta: Odonatoptera)
}

\author{
Di-YING HUANG ${ }^{1}$, JuLIÁN F. PETRULEVIČIUS ${ }^{2,3}$ and ANDRÉ NEL ${ }^{2 *}$ \\ ${ }^{1}$ State Key Laboratory of Palaeobiology and Stratigraphy, Nanjing Institute of Geology and Palaeontology, Chinese Academy \\ of Sciences, Nanjing 210008, P.R. China; e-mail: huangdiying@sina.com \\ ${ }^{2}$ CNRS UMR 7205, CP 50, Entomologie, Muséum national d'Histoire naturelle, 45 Rue Buffon, F-75005, Paris, France; \\ e-mails: levicius@mnhn.fr, anel@mnhn.fr \\ ${ }^{3}$ CONICET, Museo de La Plata, Departamento Paleozoologia Invertebrados, Paseo del Bosque, s/n, 1900 La Plata, Argentina
}

Key words. Odonatoptera, Archizygoptera, Protomyrmeleontidae, Protomyrmeleon, sp. n., China, Middle Jurassic, morphology, palaeobiology

\begin{abstract}
Protomyrmeleon daohugouensis sp. n. and Protomyrmeleon lini sp. n., two new species of Protomyrmeleontidae from the Middle Jurassic of Jiulongshan Formation are the first Chinese representatives of this Mesozoic odonatopteran family. The type specimen of $P$. lini is exceptionally well preserved, showing several particular wing and body structures that were unknown, viz. unique shape of tarsal claws, extreme thoracic skewness, presence of three pairs of long spurs on all femora and tibiae. The type "A" (sensu Nel et al., 2005) of wing venation (i.e. with a very long bridge between IR2 and RP3/4) corresponds to that of the protomyrmeleontid fore wing. The nearly complete absence of the meso-metathoracic interpleural suture, newly discovered in the Protomyrmeleontidae, can be considered as a synapomorphy of the clade Protozygoptera + Odonata.
\end{abstract}

\section{INTRODUCTION}

The Protomyrmeleontidae, a small family of Odonatoptera: Archizygoptera, sister group of modern Odonata, ranges in age from the Late Triassic to the Early Cretaceous. Members of this family superficially look like the modern damselflies with the longest petiolate wings. Protomyrmeleontids have a very particular wing venation, characterised by a unique pattern of the radial area with the main veins apparently branching off from RP3/4, instead of RP, with RP3/4 and RP2 being forked, unique among Odonatoptera. Whereas other Archizygoptera disappeared at the end of the Triassic, the Protomyrmeleontidae continued to flourish during the Jurassic and the Early Cretaceous, with genera widespread all over the World. This group of damselfly-like Odonatoptera is even more taxonomically and morphologically diverse than the true Zygoptera during the Late Jurassic. Its extinction during the Early Cretaceous remains unexplained. This family has been the subject of several recent revisions and descriptions of new genera and species, and an attempt of phylogenetic analysis (Zessin, 1991; Nel, 1992; Nel \& Henrotay, 1992; Ansorge, 1996; Martínez-Delclós \& Nel, 1996; Bechly, 1997; Henrotay et al., 1997; Nel \& Jarzembowski, 1998; Nel et al., 2005). Nevertheless they remain rather enigmatic because the great majority of fossils are only isolated wings while their body structures remain poorly known.

The present study of three new specimens constitutes, with the description of two new species, the first record of this family from the Mesozoic of China and the first Chinese representatives of the archizopteran Protozygoptera, sister group of the Odonata. One of these fossils is of special interest for its exceptional state of preservation of body structures, which add new data to our knowledge of this family, and also of the Archizygoptera, confirming the sister group relationships between them and the clade of modern Odonata.

The fossils come from the volcanic deposits of the Middle Jurassic Jiulongshan Formation near the Daohugou Village, Wuhua Township, Ningcheng County, Inner Mongolia, north-east China. These deposits have yielded very rich and exceptional fossils, such as plants, invertebrates (e.g. insects, conchostracans, anostracans, spiders, harvestman), and vertebrates (e.g. salamanders, pterosaurs, mammaliaformes) (Huang et al., 2006). The Odonatoptera are exceptionally diverse and numerous, but mainly represented by adults of the epiproctophoran lineage.

\section{TAXONOMY}

All drawings were made using a camera lucida and a binocular microscope. The nomenclature of the dragonfly wing venation is based on the interpretations of Riek \& Kukalová-Peck (1984), amended by Nel et al. (1993) and Bechly (1996). For a discussion on the very particular protomyrmeleontid wing venation, see Nel \& Henrotay (1992).

\footnotetext{
* Corresponding author.
} 


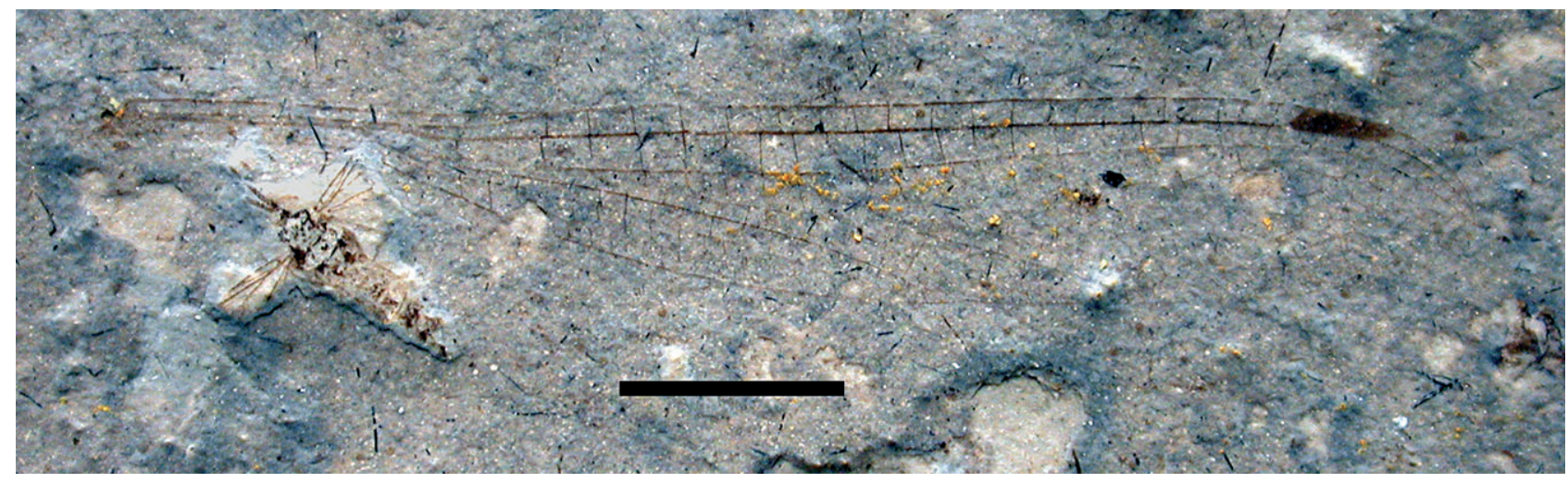

Fig. 1. Protomyrmeleon daohugouensis sp. n., holotype NIGP 151925, photograph of forewing (scale bar $=5 \mathrm{~mm})$.

\section{Suborder Archizygoptera Handlirsch, 1906 \\ Family Protomyrmeleontidae Handlirsch, 1906 Genus Protomyrmeleon Geinitz, 1887}

Type species. Protomyrmeleon brunonis Geinitz, 1887 (Lower Jurassic).

Other species. Protomyrmeleon pascholdi Zessin, 1991, $P$. anglicanus Tillyard, 1925a (both Lower Jurassic); P. jurassicus Nel, 1992, P. handlirschi Martynov, 1927, P. angustivenosus Martynov, 1927, P. pumilio Nel et al., 2005, P. kazakhstanensis $\mathrm{Nel}$ et al., 2005., P. karatauensis $\mathrm{Nel}$ et al., 2005, $P$. grandis $\mathrm{Nel}$ et al., 2005, $P$. daohugouensis sp. n., $P$. lini sp. n. (all Middle to Late Jurassic); P. cretacicus Nel \& Jarzembowski, 1998 (Lower Cretaceous).

\section{Protomyrmeleon daohugouensis sp. $\mathbf{n}$.}

\section{Figs 1-3}

Material. Holotype NIGP 151925, paratype NIGP 151926, both print and counterprint of a complete forewing (see below the description of Protomyrmeleon lini sp. n.), housed in Nanjing Institute of Geology and Palaeontology, Chinese Academy of Sciences, China.

Derivation of the name. After the Daohugou Village, locus typicus of the species.

Type locality. Near the Daohugou Village, Wuhua Township, Ningcheng County, Chifeng City, Inner Mongolia, north-east China.

Type horizon. Middle Jurassic, Jiulongshan Formation (ca. $165 \mathrm{Ma})$.

Diagnosis. Forewing (of type "A" sensu Nel et al., 2005), rather long and narrow, $31.5 \mathrm{~mm}$ long; 20 postnodal crossveins; pterostigma of medium length, $2.5 \mathrm{~mm}$ long; RP2 weakly oblique at its base; RP3/4a rudimentary; IR2 long; 2-3 rows of cells between IR1 and RP $2 \mathrm{a}$; two rows of cells between MP and posterior wing margin.

Description. Holotype NIGP 151925 (Figs 1-2). Wing hyaline, of type "A" (i.e. with a very long bridge between IR2 and RP3/4), thus probably a forewing (see below), rather narrow, $31.5 \mathrm{~mm}$ long, $4.5 \mathrm{~mm}$ wide; petiole very long and narrow, $6.0 \mathrm{~mm}$ long, $0.8 \mathrm{~mm}$ wide; antenodal crossveins Ax0, Ax1 and Ax 2 present, distance between $\mathrm{Ax} 0$ and Ax1 $2 \mathrm{~mm}$, between Ax1 and Ax2 $1.5 \mathrm{~mm}$; distance from wing base to nodus $9.6 \mathrm{~mm}$, from nodus to pterostigma $17.0 \mathrm{~mm}$, from pterostigma to wing apex 2.5 $\mathrm{mm}$, postnodal area very long, with 20 postnodal cross- veins and 18 postsubnodal cross-veins; pterostigma sclerotised, long, $2.5 \mathrm{~mm}$ long, $0.5 \mathrm{~mm}$ wide, seven cells basal of wing apex, covering three cells and a half, with basal and distal sides oblique and more or less parallel; pterostigmal brace absent; nodal cross-vein and subnodus perpendicular to RA, not aligned; RP3/4 beginning one cell distal of subnodus; presence of a very long and straight longitudinal bridge between RP3/4 and distal free part of IR2, four cells and $3.8 \mathrm{~mm}$ long, and strictly aligned with the bridge between IR2 and RP2, $2.0 \mathrm{~mm}$ long, and followed by a very long zigzagged vein that ends in IR1; IR2 apparently branching on RP3/4, true base of IR2 clearly oblique, $4.0 \mathrm{~mm}$ distal of subnodus; RP2 apparently branching on IR2, true base of RP2 weakly oblique between RP2 and RP, $8.0 \mathrm{~mm}$ distal of subnodus; true base of IR1 not individualised, but IR1 never fused with RP2; $2-3$ rows of cells between RP2 and IR 1 and one row between IR1 and RP1; RP2 divided into two long convex branches RP2a and RP2b, $0.5 \mathrm{~mm}$ distal of its fusion with the bridge between it and IR2; both RP2a and RP2b nearly straight, with four rows of cells and 2-3 zigzagged longitudinal veins between them; 1-2 rows of cells between RP $2 b$ and IR2; IR2 distally zigzagged and vanishing in area between RP3/4 and RP2; three rows of cells between IR2 and RP3/4; RP3/4 not clearly divided into two branches RP3/4a and RP3/4b, as the potential RP3/4a is strongly zigzagged; one row of cells between RP3/4 and MA; MA and MP basally straight and zigzagged at their extreme apex; two rows of cells between MP and posterior wing margin; $\mathrm{CuA}$ not independent of MP; AA not independent of AP.

Paratype NIGP 151926 (Fig. 3). Wing hyaline, also of type "A" (probably a forewing), rather narrow, dimen-

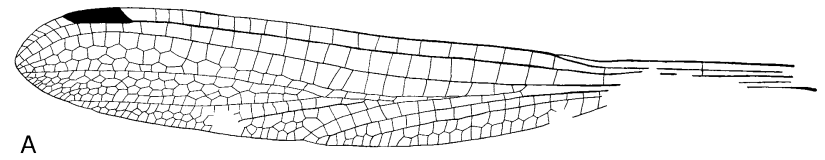

A

B

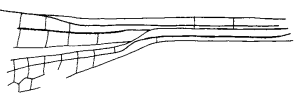

Fig. 2. Protomyrmeleon daohugouensis sp. n., holotype NIGP $151925, \mathrm{a}$ - drawing of forewing; $\mathrm{b}$ - base of counterprint (scale bar $=3 \mathrm{~mm}$ ). 

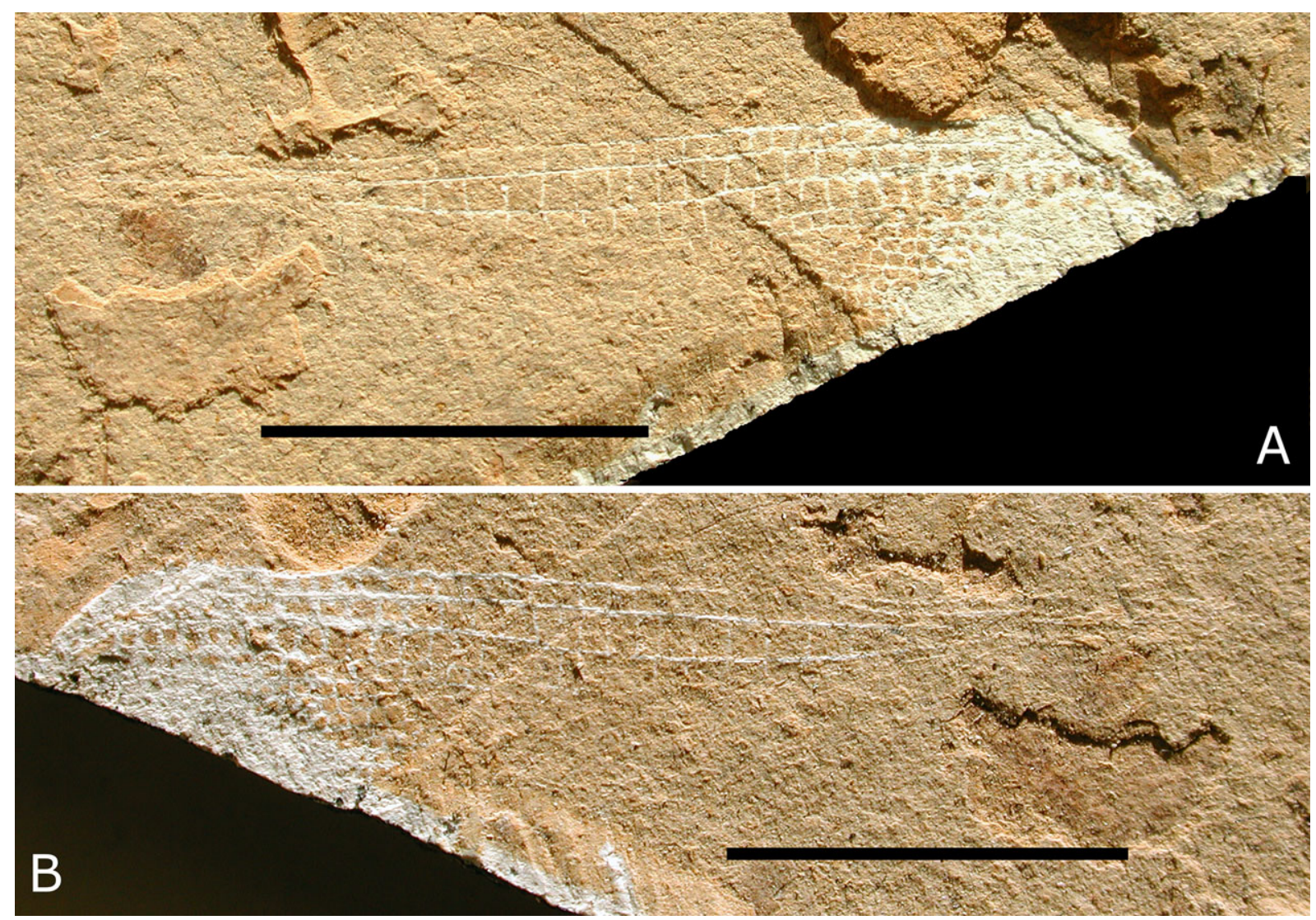

Fig. 3. Protomyrmeleon daohugouensis sp. n., paratype NIGP 151926. A - photograph of forewing print; B - photograph of forewing counterprint (scale bar $=10 \mathrm{~mm})$.

sions and differences with the holotype are as follows: wing $30.0 \mathrm{~mm}$ long, $4.9 \mathrm{~mm}$ wide; petiole very long and narrow, $6.0 \mathrm{~mm}$ long, $0.6 \mathrm{~mm}$ wide; distance from wing base to nodus $9.6 \mathrm{~mm}$, from nodus to pterostigma 16.0 $\mathrm{mm}$, from pterostigma to wing apex $2.4 \mathrm{~mm}$, postnodal area very long, with 21 postnodal cross-veins and postsubnodal cross-veins; pterostigma sclerotised, long, 2.5 $\mathrm{mm}$ long, $0.5 \mathrm{~mm}$ wide, covering three cells and a half; three rows of cells between MP and posterior wing margin.

Discussion. These two fossils are very similar, and share the specific diagnostic characters, especially the wing sizes, number of postnodal crossveins, base of RP2 weakly oblique, and RP3/4a rudimentary. Thus we consider them as conspecific. They can be attributed to the genus Protomyrmeleon Geinitz, 1887 for the structure of the bridge between RP3/4, IR2, RP2, and IR1, viz. IR2 independent of RP2 and presence of a "double" bridge between IR2 and RP2 (Nel et al., 2005). This genus comprises no less than 11 species. $P$. daohugouensis differs from P. karatauensis Nel et al., 2005, P. kazakhstanensis Nel et al., 2005, P. pumilio Nel et al., 2005, P. jurassicus Nel, 1992, P. pascholdi Zessin, 1991, and P. brunonis Geinitz, 1887 in the RP3/4a extremely reduced (Zessin, 1991; Nel, 1992; Nel \& Henrotay, 1992; Ansorge, 1996; Nel et al., 2005). It differs from $P$. cretacicus Nel \& Jarzembowski, 1998 in the less numerous postnodal crossveins, the shorter basal part of RP3/4 and the longer basal part of IR2 (Nel \& Jarzembowski, 1998). P. handlirschi Martynov, 1927 has a distinctly shorter independent IR2, with a reduced area between RP2b and RP3/4, unlike $P$. daohugouensis (Martynov, 1927; Nel \& Henrotay, 1992). P. anglicanus Tillyard, 1925 has only one row of cells between IR1 and RP2a and a long RP3/4a (Tillyard, 1925). P. angustivenosus Martynov, 1927 is a poorly defined species hardly comparable to all the other species (Nel \& Henrotay, 1992). P. grandis Nel et al., 2005 has a poorly defined, strongly zigzagged RP3/4a similar to the evanescent one of $P$. daohugouensis. More generally their wing venations are very similar, except in the shorter wing in $P$. daohugouensis $(31.5 \mathrm{~mm}$ long contra 32.5 to $35.4 \mathrm{~mm}$ for $P$. grandis), and a distinctly shorter pterostigma $(2.5 \mathrm{~mm}$ long contra 3.0 to $4.2 \mathrm{~mm}$ long for $P$. grandis).

\section{Protomyrmeleon lini sp. $\mathbf{n}$.}

Figs 4-6

Material. Holotype NIGP 151927, print and counterprint of a body, with two complete forewings and five basal abdominal segments attached, female (for the absence of the male secondary genital structure on second abdominal segment, present in male Protozygoptera and Odonata), housed in Nanjing Institute of Geology and Palaeontology, Chinese Academy of Sciences, China.

Derivation of the name. After our colleague Prof. Lin Qi-bin. 

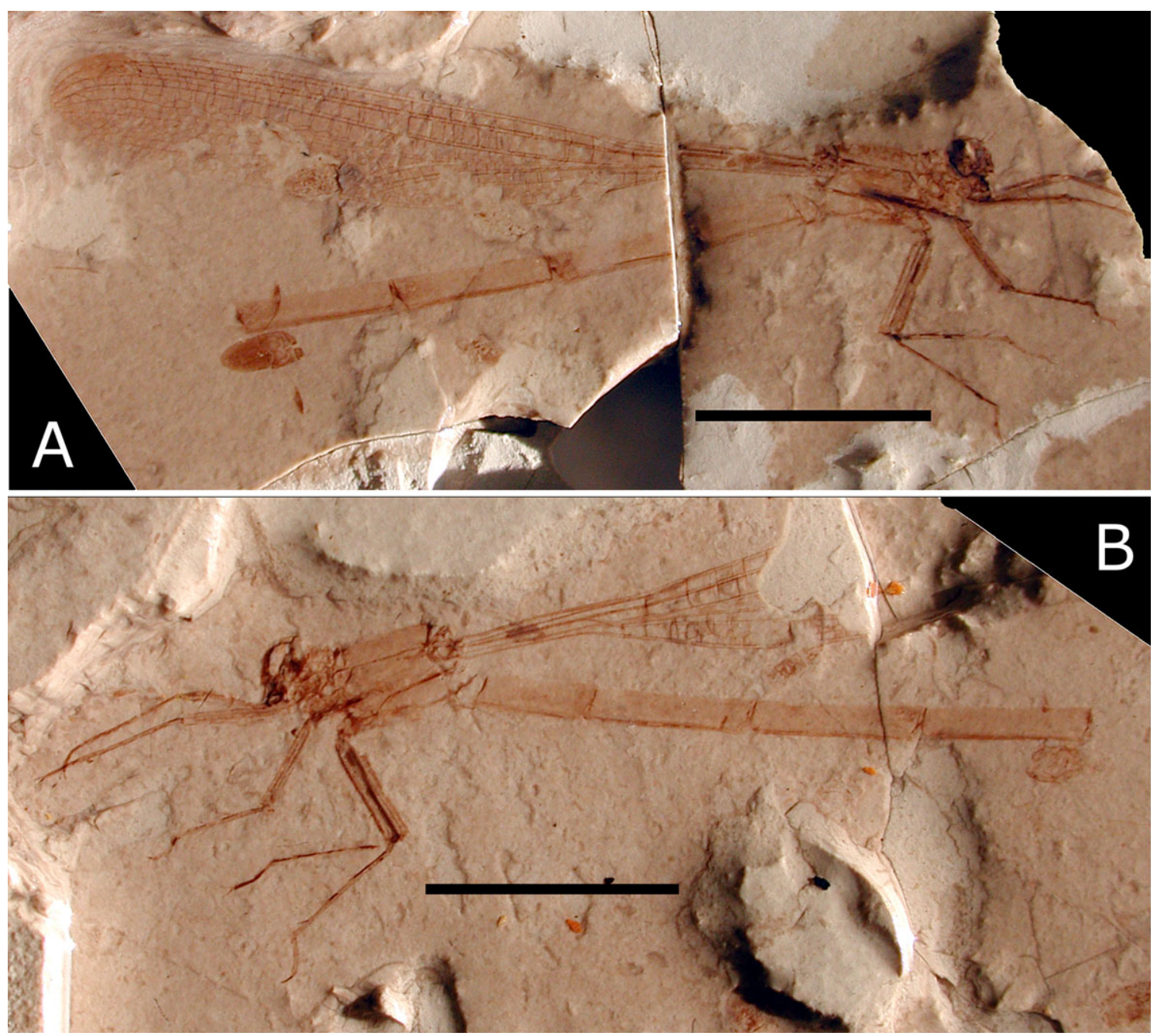

Fig. 4. Protomyrmeleon lini sp. n., holotype NIGP 151927. A - photograph of habitus print; B - photograph of habitus counterprint $($ scale bar $=10 \mathrm{~mm})$.

Type locality. Near the Daohugou Village, Wuhua Township, Ningcheng County, Chifeng City, Inner Mongolia, north-east China.

Type horizon. Middle Jurassic, Jiulongshan Formation (ca. $165 \mathrm{Ma})$.

Diagnosis. Forewing (of type "A" sensu Nel et al., 2005), rather long and narrow, $33.0 \mathrm{~mm}$ long; numerous (24) postnodal crossveins; pterostigma rather long and close to wing apex; RP2 distinctly oblique at its base; RP3/4a well developed; IR2 long; two rows of cells between RP1 and RP2a; area between branches of RP2 broad with cells regularly disposed; two rows of cells between MP and posterior wing margin.

Description. Holotype NIGP 151927. Both wings hyaline, of type "A" (i.e. with a very long bridge between IR2 and RP3/4), attached to mesothorax, thus forewings, rather narrow, $33.0 \mathrm{~mm}$ long, $5 \mathrm{~mm}$ wide; petiole very long and narrow, $6.5 \mathrm{~mm}$ long, $0.55 \mathrm{~mm}$ wide; antenodal crossveins $\mathrm{Ax} 0, \mathrm{Ax} 1$ and $\mathrm{Ax} 2$ present, distance between $\mathrm{Ax} 0$ and Ax1 $2.5 \mathrm{~mm}$, between $\mathrm{Ax} 1$ and $\mathrm{Ax} 21.5 \mathrm{~mm}$; distance from wing base to nodus $9.7 \mathrm{~mm}$, from nodus to pterostigma $19.8 \mathrm{~mm}$, from pterostigma to wing apex 2.0 $\mathrm{mm}$, postnodal area very long, with 26 postnodal cross- veins and circa 24 postsubnodal cross-veins; pterostigma sclerotised, long, $3.0 \mathrm{~mm}$ long, $0.7 \mathrm{~mm}$ wide, covering three cells and a half, with basal and distal sides oblique and more or less parallel; pterostigmal brace absent; nodal cross-vein and subnodus perpendicular to RA, aligned; RP3/4 beginning one cell distal of subnodus; presence of a very long and straight longitudinal bridge between RP3/4 and distal free part of IR2, five cells and $4.0 \mathrm{~mm}$ long, and strictly aligned with the bridge between IR2 and RP2, $2.5 \mathrm{~mm}$ long, and followed by a very long zigzagged vein that ends in IR1; IR2 apparently branching on RP3/4, true base of IR2 clearly oblique, $3.5 \mathrm{~mm}$ distal of subnodus; RP2 apparently branching on IR2, true base of RP2 distinctly oblique between RP2 and RP, $8.8 \mathrm{~mm}$ distal of subnodus; true base of IR1 not individualised, but IR1 never fused with RP2; one (exceptionally divided in two cells) row of cells between RP2 and IR 1 and one row between IR1 and RP1; RP2 divided into two long convex branches RP2a and RP2b, $0.6 \mathrm{~mm}$ distal of its fusion with the bridge between it and IR2; both RP2a and RP2b nearly straight, with three rows of cells and two zigzagged longitudinal veins between them; $1-2$ rows of cells between RP2b and IR2; IR2 distally zigzagged and 


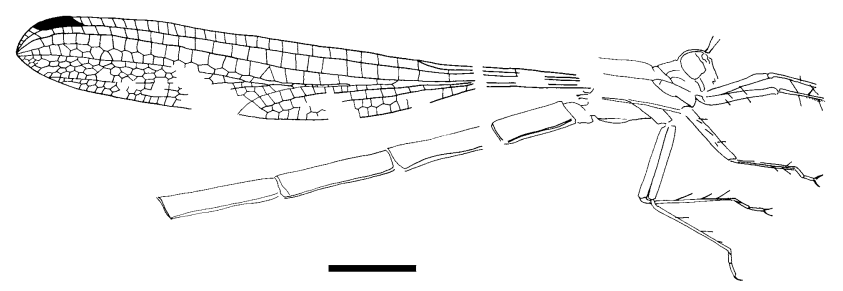

Fig. 5. Protomyrmeleon lini sp. n., holotype NIGP 151927 , drawing of habitus (scale bar $=5 \mathrm{~mm}$ ).

vanishing in area between RP3/4 and RP2; three rows of cells between IR2 and RP3/4; RP3/4 clearly divided into two branches RP3/4a and RP3/4b, with base of RP3/4a clearly visible, even if its distal part is not preserved; one row of cells between RP3/4 and MA; MA and MP basally straight and zigzagged at their extreme apex; two rows of cells between MP and posterior wing margin; $\mathrm{CuA}$ not independent of MP; AA not independent of AP.

Legs long and slender; fore femur $4.0 \mathrm{~mm}$ long, $0.4 \mathrm{~mm}$ wide, tibia $4.5 \mathrm{~mm}$ long, $0.2 \mathrm{~mm}$ wide, first tarsal segment $0.2 \mathrm{~mm}$ long, second $0.5 \mathrm{~mm}$, third $0.6 \mathrm{~mm}$; mid femur $4.5 \mathrm{~mm}$ long, $0.4 \mathrm{~mm}$ wide, tibia $3.6 \mathrm{~mm}$ long, 0.1 $\mathrm{mm}$ wide, first tarsal segment $0.1 \mathrm{~mm}$ long, second 0.2 $\mathrm{mm}$, third $0.3 \mathrm{~mm}$; hind femur $4.5 \mathrm{~mm}$ long, $0.4 \mathrm{~mm}$ wide, tibia $5.5 \mathrm{~mm}$ long, $0.2 \mathrm{~mm}$ wide, first tarsal segment $0.2 \mathrm{~mm}$ long, second $0.6 \mathrm{~mm}$, third $0.6 \mathrm{~mm}$; all femora and tibia with three pairs of long spurs and a double series of very small spines (Figs 4, 6B); no clearly defined comb on fore tibia; tarsi long, three-segmented; all claws very long and weakly curved, with no subapical but a basal tooth (see Fig. 6B).

Head visible in profile (Fig. 6A), $1.4 \mathrm{~mm}$ long, $2.8 \mathrm{~mm}$ high, compound eye elliptical $(0.5 \times 1.5 \mathrm{~mm})$; postfront flat, antefront convex, 0.2 high, postclypeus + anteclypeus circa $0.7 \mathrm{~mm}$ high; antenna three-segmented, 1.1 $\mathrm{mm}$ long, first antennomere rounded, broad, and short, second and third elongate and narrow.

Pterothorax visible in profile (Fig. 6A), very elongate, $4.5 \mathrm{~mm}$ high; episternum $23.4 \mathrm{~mm}$ long, $0.9 \mathrm{~mm}$ wide; meso-metathoracic interpleural suture absent or extremely reduced (no suture near posterior part of meso-metathorax near the wing base, and, perhaps, a rudiment of suture in anterior part, near base of mid leg; (epimeron $2+$ episternum 3) $4.5 \mathrm{~mm}$ long, $1.4 \mathrm{~mm}$ wide; epimeron $33.4 \mathrm{~mm}$ long, $0.7 \mathrm{~mm}$ wide; metapostepimeron not clearly visible; thoracic skewness strongly pronounced (angle $\mathrm{x}$ circa $74^{\circ}$, angle g circa $60^{\circ}$ ) (sensu Needham \& Anthony, 1903).

Abdomen very narrow and delicate, first segment 2.0 $\mathrm{mm}$ long, second $4.5 \mathrm{~mm}$, third $6.5 \mathrm{~mm}$, fourth $7.0 \mathrm{~mm}$, fifth $6.5 \mathrm{~mm}$; swelling of abdominal articulation and ventral carina present on segments 2 to 5 , but no transverse carina (sensu Asahina, 1954).

Discussion. This fossil differs from $P$. daohugouensis in the longer postnodal area with distinctly more postnodal crossveins (24 instead of 20 in the latter), presence of a better defined RP3/4a, a more oblique RP2 at it base, longer pterostigma but in a more distal position, closer to wing apex (only five cells instead of seven cells distant
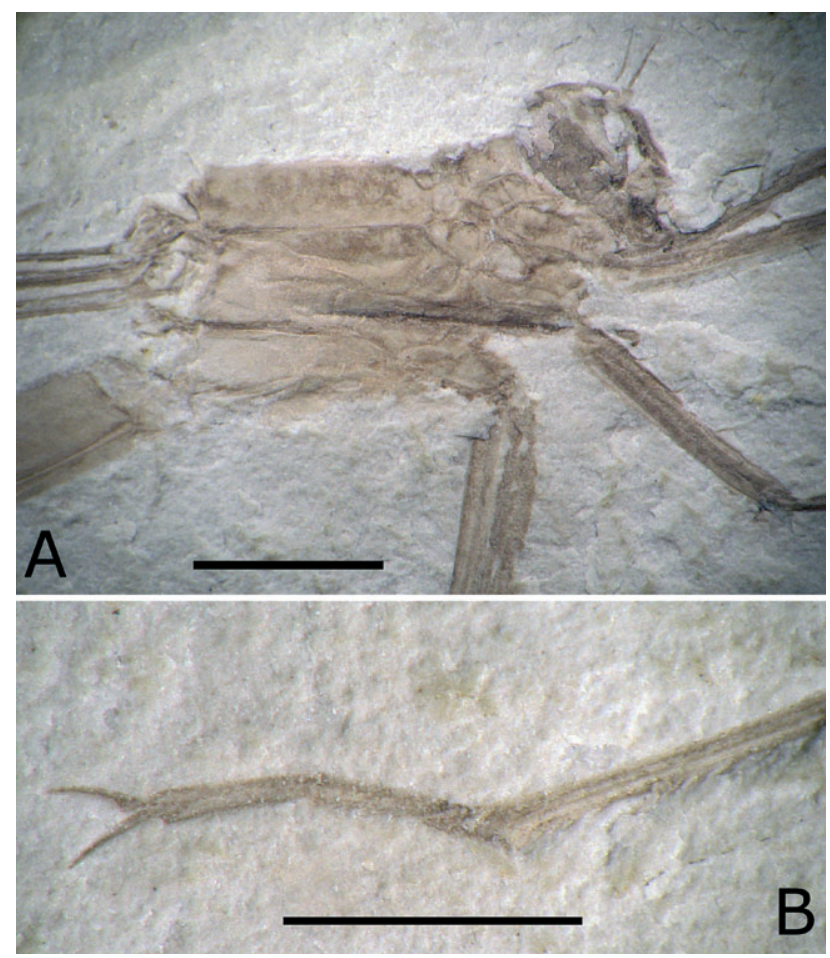

Fig. 6. Protomyrmeleon lini sp. n., holotype NIGP 151927. A - photograph of head and thorax with appendages in lateral view (scale bar represents $2 \mathrm{~mm}$ ); B - photograph of mid tarsus (scale bar $=0.5 \mathrm{~mm}$ ).

from wing apex). Thus we consider that it corresponds to a different Protomyrmeleon species. P. cretacicus, $P$. jurassicus, $P$. grandis and $P$. kazakhstanensis differ from $P$. lini in the greater number of rows of cells between RP1 and RP2a. P. lini has distinctly more postnodal crossveins than $P$. brunonis. P. karatauensis has only 17 postnodals while $P$. pumilio has 15 . P. handlirschi has a shorter distal free part of IR2. $P$. pascholdi has a narrower area between the branches of RP2. P. anglicanus has a more irregular net of cells in the same area.

\section{PROTOMYRMELEONTID MORPHOLOGY AND PALAEOBIOLOGY}

The type specimen of $P$. lini is of great interest in terms of our understanding of several structures of Protomyrmeleontidae. Its preserved wings are both forewings and both are of type "A" sensu Nel et al. (2005). This allows us to determine that the protomyrmeleontid wings of type "A" (bridge between RP3/4 and IR2 long and closely parallel to RP3/4) are forewings while those of type " $B$ " (bridge between RP3/4 and IR2 distinctly shorter and more distant from RP3/4) are hindwings, while Nel et al. (2005) could not decide due to the state of the available material at that time.

The nearly complete absence of the meso-metathoracic interpleural suture is a character that was previously completely unrecorded in the whole clade Protozygoptera. Bechly (1996) considered that the reduction of this suture was a synapomorphy of the Odonata, sister group of Protozygoptera (but reversed in Calopterygiformia) (see also Asahina, 1957). The present discovery shows that it is 
more likely a synapomorphy of the clade Protozygoptera + Odonata.

The strongly pronounced thoracic skewness of this Protomyrmeleontidae is comparable to that of the most modified thorax of the small damselflies (Coenagrionomorpha Aciagrion) (Needham \& Anthony, 1903). This is certainly related to convergent adaptation to similar habits of life. The rather weak legs with three pairs of long and sharp spines on both femora and tibia also support the thesis of adaptation for capturing small, flying prey (small flies, etc.).

Similarities in the body structures between small, true damselflies and the Protomyrmeleontidae suggest that the adults of both clades had similar chorologies. Protomyrmeleontidae appeared during the Upper Triassic and their last known representatives are from Lower Cretaceous, while small, true damselflies are known from the Lower Cretaceous (Lak et al., 2009). A third group of damselflylike Odonata existed in the Jurassic: the Isophlebioptera: Asiopteridae. These three lineages co-existed during at least the main part of Lower Cretaceous. The Jurassic diversification of the Asiopteridae and that of the Lower Cretaceous small, true damselflies was clearly not sufficient to cause the extinction of the Protomyrmeleontidae. Their extinction seems to be concomitant with that of several other "old" Mesozoic lineages (Aeschnidiidae, etc.), at the boundary between the Lower and the Upper Cretaceous, during the Albian-Cenomanian-Turonian. This period is crucial for a large turnover among the odonatopteran groups, perhaps in relation with the ecological and chemical changes in the freshwater ecosystems about 100 Myr ago (Nel et al., 2010).

ACKNOWLEDGEMENTS. We acknowledge financial support from the National Science Foundation of China (grants no. 40672013 and 40632010), Chinese Academy of Sciences (grant no. KZCX2-YW- QN104), and the Major Basic Research Projects (2006CB806400) of MST of China. JFP thanks for the invitation to the National Museum of Natural History of Paris (MNHN) and the funds provided for this research: grants PIP 6393, PIP 11420090100377 and BEJI from the National Research Council of Argentina (CONICET).

\section{REFERENCES}

AnsoRge J. 1996: Insekten aus dem Oberen Lias von Grimmen (Vorpommern, Norddeutschland). Neue Paläontol. Abh. 2: $1-132$.

Asahina S. 1954: A Morphological Study of a Relict Dragonfly Epiophlebia superstes Selys (Odonata, Anisozygoptera). The Japan Society for the Promotion of Science, Tokyo, 153 pp.

AsAHINA S. 1957: On the pterothoracic interpleural suture of Mesozoic and recent Odonata. J. Fac. Sci. Hokkaido Univ. (VI, Zool.) 13: 1-7.
BECHLY G. 1996: Morphologische Untersuchungen am Flügelgeäder der rezenten Libellen und deren Stammgruppenvertreter (Insecta; Pterygota; Odonata), unter besonderer Berücksichtigung der Phylogenetischen Systematik und des Grundplanes der *Odonata. Petalura (Böblingen) (Spec. Vol.) 2: 402 pp.

Huang D.-Y., Nel A., Shen Y.-B., Selden P.A. \& Lin Q.-B. 2006: Discussions on the age of the Daohugou fauna - evidence from invertebrates. Progr. Nat. Sci. (Spec. Issue) 16: 308-312.

Lak M., Fleck G., Azar D., Engel M.S., Kaddumi H.F., Neraudeau D., Tafforeau P. \& Nel A. 2009: Phase contrast $\mathrm{X}$-ray synchrotron imaging and the oldest damselflies in amber (Odonata: Zygoptera: Hemiphlebiidae). Zool. J. Linn. Soc. 156: 913-923.

Martynov A.V. 1927: Jurassic fossil insects from Turkestan. 7. Some Odonata, Neuroptera, Thysanoptera. Bull. Acad. Sci. URSS (Sci. Math. Nat.) 20: 757-768 [in Russian].

Needham J.G. \& Anthony M.H. 1903: The skewness of the thorax in the Odonata. J. N. Y. Entomol. Soc. 11: 117-123.

Nel A. 1992: Redescription de la libellule fossile du Jurassique supérieur "?Malmagrion eichstaettense (Hagen, 1862)" (Odonatoptera, Odonata, Archizygoptera). Bull. Soc. Entomol. Fr. 96: $433-442$.

Nel A. \& Henrotay M. 1992: Les Protomyrmemelontidae (Odonatoptera, Odonata, Archizygoptera stat. rest.): état actuel des connaissances. Ann. Paléontol. (Vert.-Invert.) 78: $1-47$.

Nel A. \& Jarzembowski E.A. 1998: New Protomyrmeleontid dragonflies from the Lower Cretaceous of Southern England. (Insecta, Odonata, Archizygoptera). Cretac. Res. 19: 393-402.

Nel A., Martínez-Delclòs X., Paicheler J.-C. \& Henrotay M. 1993: Les "Anisozygoptera" fossiles. Phylogénie et classification. (Odonata). Martinia (Spec. Issue) 3: 1-311.

Nel A., Petrulevičíus J.F. \& Martínez-Delclòs X. 2005: New Mesozoic Protomyrmeleontidae (Insecta: Odonatoptera: Archizygoptera) from Asia with a new phylogenetic analysis. J. Syst. Palaeontol. 3: 187-201.

Nel A., Nel P., Petrulevičius J.F., Perrichot V., Prokop J. \& AzAR D. 2010: The Wagner parsimony using morphological characters: a new method for palaeosynecological studies. Ann. Soc. Entomol. Fr. (N.S.) 46: 276-292.

Riek F. \& KuKalovÁ-Peck J. 1984: A new interpretation of dragonfly wing venation based upon early Upper Carboniferous fossils from Argentina (Insecta: Odonatoidea) and basic character states in pterygote wings. Can. J. Zool. 62: $1150-1166$.

Tillyard R.J. 1925: The British Liassic Dragonflies. Fossil Insects 1. British Museum (Natural History), London, pp. $1-39$.

Zessin W. 1991: Die Phylogenie der Protomyrmeleontidae unter Einbeziehung neuer oberliassischer Funde (Odonata: Archizygoptera sens. nov.). Odonatologica 20: 97-126.

Received March 19, 2010; revised and accepted May 10, 2010 